\title{
Cholinergic regulation of the rat adrenal zona glomerulosa
}

\author{
A Jánossy, E Orsó, K Sz Szalay, Z Jurányi, M Beck, E S Vizi \\ and $\mathbf{G} \mathbf{P}$ Vinson ${ }^{\mathbf{1}}$ \\ Institute of Experimental Medicine, Hungarian Academy of Sciences, PO Box 67, H-1450 Budapest, Hungary and ${ }^{1}$ Department of Biochemistry, Faculty of \\ Basic Medical Sciences, Queen Mary and Westfield College, Mile End Road, London E1 4NS, UK \\ (Requests for offprints should be addressed to A Jánossy) \\ (E Orsó is now at Institute for Clinical Chemistry and Laboratory Medicine, University Clinic of Regensburg, D-93042 Regensburg, Germany)
}

\begin{abstract}
Using histochemical and immunocytochemical methods, cholinergic nerve fibres were demonstrated in the rat adrenal cortex, primarily in the capsule and zona glomerulosa, and in the medulla. Some terminated among the glomerulosa cells or around blood vessels. Occasional fibres were also seen in the fasciculata, ending in islets of chromaffin tissue without ramifications on cortical cells.

To clarify the role of cholinergic innervation, a microvolume perifusion system was used to study steroid production by the rat adrenal capsule-glomerulosa. Acetylcholine (ACh) itself had no reproducible effects; however, since variable amounts of endogenous ACh were present, the actions of antagonists were also studied. The $M_{1}$ muscarinic receptor antagonist pirenzepine (10 and $100 \mu \mathrm{M})$ stimulated aldosterone secretion. This stimulation was abolished by co-incubation with carbachol, the $\mathrm{M}_{1}$ agonist $\mathrm{McN} \mathrm{A}-343$ and by atropine. We found that the action of pirenzepine was blocked by nifedipine $\left(\mathrm{Ca}^{2+}\right.$ channel blocker), suggesting that pirenzepine (through
\end{abstract}

release of endogenous $\mathrm{ACh}$ ) provides an acute stimulus by enhancing $\mathrm{Ca}^{2+}$ inflow. Hemicholine, a choline uptake blocker, reduced the stimulatory effect of pirenzepine on steroid secretion, confirming that stimulation was of neural origin. Neither the non-selective muscarinic receptor antagonist atropine, the selective $\mathrm{M}_{1}-\mathrm{M}_{3}$ muscarinic receptor antagonist 4-DAMP, nor the selective $M_{2}$ muscarinic receptor antagonist methoctramine influenced aldosterone output. Receptor-binding studies revealed the existence of $\mathrm{M}_{3}$ receptors in capsule-glomerulosa homogenates. We conclude that pirenzepine acts on presynaptic $M_{1}$ autoreceptors to increase spontaneous ACh release from varicose axon terminals that lie in close proximity to the glomerulosa cells. In turn ACh may thus stimulate steroidogenesis acutely through $\mathrm{M}_{3}$ receptors. These results support the concept of a direct cholinergic influence on zona glomerulosa function in the rat.

Journal of Endocrinology (1998) 157, 305-315

\section{Introduction}

Although the hypothalamo-hypophyseal regulation of adrenocortical corticosteroid secretion seems to be fairly well understood, the role of neurotransmitters in the fine tuning of steroid synthesis has been only recently studied (for reviews see Holzwarth et al. 1987, Parker et al. 1993, Vinson et al. 1994, Tóth et al. 1997).

It is well established that the adrenal gland is supplied by preganglionic and postganglionic nerves, and the adrenal medulla receives the most dense nerve supply. However, the adrenal cortex is also innervated, especially the outer capsule-glomerulosa region. The presence and function of catecholaminergic innervation in the rat zona glomerulosa have been studied in detail. Morphological and neurochemical evidence showed that a substantial proportion of catecholaminergic (noradrenergic) varicose axon terminals lie in close proximity to the zona glomerulosa cells without making synaptic contact (Vizi et al. 1992). This arrangement provides the possibility for fine tuning of corticosteroid synthesis and secretion via the stimulation of $\beta_{1}$ and/or $\mathrm{DA}_{2}$ receptors located on the surface of glomerulosa cells (Vizi et al. 1993).

In addition to catecholaminergic innervation, the presence of cholinergic nerve fibres has been shown in rat (Purwar 1978, Parker et al. 1993), guinea pig (Parker et al. 1993), marmoset (Parker et al. 1993) and human (Charlton et al. 1991) adrenals. Several groups have reported actions of acetylcholine (ACh) on adrenocortical steroid secretion in frog (Benyamina et al. 1987), calf (Jones et al. 1991), bovine (Hadjian et al. 1982, Kojima et al. 1986, Walker et al. 1990, 1991) and human (Stern et al. 1989) adrenals.

The capsule-glomerulosa preparation of the rat adrenal consists of the connective tissue capsule, zona glomerulosa cells, local nerve endings and vascular tissue (arterioles, capillaries and some sinusoids), but with little fasciculata and no medullary tissue, although occasional groups of chromaffin cells are present in the capsule-glomerulosa region (Kovács \& Horváth 1973, Palacios \& Lafarga 1975). The advantage of this capsule-glomerulosa preparation is 
that the cytoarchitecture of the capsular gland is preserved and the local nerve endings and glomerulosa cells retain their relationships. This paper describes the use of this preparation in studies on the role of cholinergic innervation in the rat adrenal.

\section{Materials and Methods}

\section{Preparation of capsule-glomerulosa}

Male Sprague-Dawley rats weighing 150-170 g were killed and decapitated, and the adrenals were removed and freed from adipose tissue. The glands were hemisected, and the capsule-glomerulosa portion of adrenals was carefully separated from the remainder of the gland.

In vitro perifusion of adrenal capsule-glomerulosa preparation

Two capsules were placed into chambers of a microvolume four-channel perifusion system. The tissues were perifused with Krebs-Ringer bicarbonate buffer (in mM: $\mathrm{NaCl}, 113 ; \mathrm{KCl}, 4 \cdot 7 ; \mathrm{CaCl}_{2}, 25 ; \mathrm{KH}_{2} \mathrm{PO}_{4}, 1 \cdot 2 ; \mathrm{MgSO}_{4}$, 1.2; $\mathrm{NaHCO}_{3}, 2 \cdot 5$; glucose, $11 \cdot 5 ; 0.25 \%$ human serum albumin; saturated with $\left.95 \% \mathrm{O}_{2} / 5 \% \mathrm{CO}_{2}\right), \mathrm{pH} 7 \cdot 4$, maintained at $37{ }^{\circ} \mathrm{C}$ at a constant flow rate of $0.7 \mathrm{ml} / \mathrm{min}$. After steroid secretion reached equilibrium within $2 \mathrm{~h}$, the effluent was collected in $5 \mathrm{~min}$ fractions and stored for subsequent assay of steroids. The first six fractions were calculated as basal secretion. The following drugs were assayed: ACh (acetylcholine iodide), carbachol (carbamylcholine chloride), atropine hydrochloride (Sigma Co., St Louis, MO, USA), McN-A-343 ((4-hydroxy-2-butyryl)1-trimethylammonium-m-chlorocarbanilate chloride), 4DAMP (4-diphenylacetoxy- $N$-methylpiperidine), methoctramine tetrahydrochloride, pirenzepine hydrochloride, hemicholine (hemicholinium-3), nifedipine (RBI, Natick, MA, USA). ACh was infused for $15 \mathrm{~min}$, and all other drugs for $20 \mathrm{~min}$. The cholinesterase inhibitor physostigmine $(10 \mu \mathrm{M}$; Sigma) was added to all ACh solutions.

\section{Determination of endogenous ACh content}

The endogenous ACh content of the tissue was measured by bioassay (Vizi et al. 1985).

\section{Localization of cholinergic neuronal elements in rat adrenal tissue}

Cholinergic neuronal elements in rat adrenal gland were localized using histochemical and immunocytochemical techniques for acetylcholinesterase (AChE, EC 3.1.1.7) and choline acetyltransferase (ChAT, EC 2.3.1.6).

Enzyme histochemistry for AChE A thiocholine method, as described by Karnovsky \& Roots (1964), was used with minimal modification. Adrenal glands from two male rats were cut into small pieces and fixed in 0.028 mol/1 Tris-maleate buffer containing paraformaldehyde $(40 \mathrm{~g} / \mathrm{l})$ and sucrose $(75 \mathrm{~g} / \mathrm{l})$. Tissue was fixed for $3 \mathrm{~h}$ at $4{ }^{\circ} \mathrm{C}$ in the dark, then washed overnight in Tris-maleate buffer containing $75 \mathrm{~g} / 1$ sucrose at $4{ }^{\circ} \mathrm{C}$. Frozen sections $(20 \mu \mathrm{m})$ were incubated for $30 \mathrm{~min}$ at $37^{\circ} \mathrm{C}$ in the following medium: acetylthiocholine iodide substrate $(3.125 \mathrm{~g})$ was dissolved in $18.3 \mathrm{ml} 0.863 \mathrm{M}$ sodium acetate buffer, and supplemented with the following materials in order: $0.5 \mathrm{ml} 6 \mathrm{~g} / 1$ acetic acid, $1.5 \mathrm{ml} 29.4 \mathrm{~g} / 1$ sodium citrate, $2.5 \mathrm{ml} 75 \mathrm{~g} / 1 \mathrm{CuSO}_{4}$ and $2.5 \mathrm{ml} 1.65 \mathrm{~g} / 1$ potassium ferricyanide. The incubation reaction was stopped by washing the sections in Tris-maleate buffer for $3 \times 5 \mathrm{~min}$. The sections were covered by Aquatex (Merck KGaA, Darmstadt, Germany) and studied by light microscopy.

To verify the specificity of the reaction product, control incubations were carried out (a) in the absence of substrate, (b) in the presence of the cholinesterase inhibitor physostigmine $(10 \mu \mathrm{M})$, or (c) in the presence of the pseudocholinesterase inhibitor, iso-OMPA tetraisopropyl pyrophosphoramide (10 $\mu \mathrm{M}$; Sigma).

Immunocytochemistry for ChAT Three male Wistar rats (160-180 g) were perfused transcardially under chlornembutal anaesthesia first with $9 \mathrm{~g} / 1 \mathrm{NaCl}$ for $1 \mathrm{~min}$, then with the following fixative: $40 \mathrm{~g} / 1$ paraformaldehyde, $150 \mathrm{ml} / 1$ saturated picric acid, $0 \cdot 3 \mathrm{~g} / 1$ glutaraldehyde in $0 \cdot 1 \mathrm{M}$ sodium phosphate buffer $(\mathrm{pH} 7 \cdot 3)$. Adrenals and brains (sections containing brain septum) were removed and fixed for a further $4 \mathrm{~h}$ at $4{ }^{\circ} \mathrm{C}$ in the same fixative. The $50 \mu \mathrm{m}$-thick sections (optimal for following neuronal arborization and branching within the sections) were prepared using a vibratome. For pre-embedding electron microscopic localization of ChAT, a free floating technique was used. The sections were washed in $0.1 \mathrm{M}$ sodium phosphate buffer for $5 \times 25 \mathrm{~min}$. After cryprotection with $300 \mathrm{~g} / 1$ sucrose, freeze-thawing in liquid nitrogen was carried out to produce permeabilization. Sections were then washed in $0.05 \mathrm{~mol} / 1$ Tris-buffered saline (TBS, pH 7.3) and digested with Pronase-E $(10 \mathrm{~g} / 1$ in TBS; Sigma) for $10 \mathrm{~min}$ at room temperature. Digestion was stopped by washing the sections in ice-cold TBS. ChAT binding sites were visualized using the avidinbiotin horseradish peroxidase complex (ABC) technique. Briefly, sections were incubated first with $20 \%$ normal goat serum for $30 \mathrm{~min}$, then for 2 days at $4{ }^{\circ} \mathrm{C}$ in the primary antiserum raised in rabbit against human $\alpha$-ChAT (1:1000; gift from L B Hersh) (German et al. 1985, Amstrong et al. 1987, Tago et al. 1987). Bound antibody was detected by avidin-biotin affinity peroxidase staining using a commercially available kit (Vectastaine Elite ABC Kit; Vector Laboratories, Burlingame, CA, USA), and the peroxidase reaction was visualized with nickel-intensified $3,3^{\prime}$-diaminobenzidine hydrochloride. At the end of the procedure the sections were postfixed in $1 \% \mathrm{OsO}_{4}$, 
dehydrated in ascending ethanol series and propylene oxide, embedded in Durcupan ACM (Fluka Chemie AG, Buchs, Switzerland) and studied by light microscopy.

For electron microscopy, small areas of vibratome sections containing the capsule-glomerulosa region or a part of the adrenal medulla were selectively cut under stereomicroscopic control and re-embedded in Durcupan ACM.

Primary antiserum was omitted from control incubations.

\section{Hormone assays}

The corticosterone concentration of the perfusion medium was determined by RIA using iodinated corticosterone-3carboxymethyloxime tyrosine methyl ester and a corticosterone antibody developed in our laboratory. In this assay, sensitivity was $0 \cdot 15-80 \mathrm{pmol} / \mathrm{ml}$, interassay variation $10 \%$ and intra-assay variation $5 \cdot 5 \%$.

The aldosterone concentration of the medium was determined after chloroform extraction, by RIA without chromatographic separation, as described previously (Szalay 1981).

\section{Binding studies}

Capsule-glomerulosa tissues were homogenized in 10 volumes $(\mathrm{w} / \mathrm{v})$ of ice-cold sodium-potassium phosphate buffer $(50 \mathrm{mM}, \mathrm{pH} 7 \cdot 4)$ containing $0.32 \mathrm{M}$ sucrose. Homogenates were centrifuged at $1000 \mathrm{~g}$ for $10 \mathrm{~min}$, the pellets discarded and the supernatants re-centrifuged at $19000 \mathrm{~g}$ for $20 \mathrm{~min}$. The pellets were resuspended in ice-cold sodium-potassium phosphate buffer $(50 \mathrm{mM}, \mathrm{pH}$ 7.4) and diluted to a final protein concentration of $1 \mathrm{mg} / \mathrm{ml}$ for binding assays. Muscarinic cholinergic receptor binding studies were performed with the non-selective receptor antagonist $\left[{ }^{3} \mathrm{H}\right]$ quinuclidinyl benzilate $(\mathrm{QNB})$ as radioligand. Incubation was carried out for $45 \mathrm{~min}$ at $37^{\circ} \mathrm{C}$. At each concentration of radioligand, total binding was determined in triplicate, and non-specific binding, defined as radioligand binding in the presence of $1 \mu \mathrm{M}$ atropine, was determined in duplicate. In competition studies, $0 \cdot 1 \mathrm{nM}\left[{ }^{3} \mathrm{H}\right] \mathrm{QNB}$ binding was measured in the presence of different concentrations of drugs. Bound ligand was separated from free by vacuum filtration on GF/B glass-fibre filters (Whatman, Maidstone, Kent, UK). The filters were rinsed three times with $5 \mathrm{ml}$ buffer, and bound radioactivity was estimated in the liquid scintillation spectrometer.

\section{Statistical analysis}

Values are means \pm S.E.M. Statistical comparisons between control and different drug effects were made by one- and two-way ANOVA, followed by the Scheffé multiple comparison test.

\section{Results}

\section{Demonstration of cholinergic neuronal elements in rat} adrenal tissue

Light microscopic staining for AChE At the light microscope level, fine cholinergic nerve fibres stained for AChE were seen in the adrenal cortex, while the adrenal medulla was strongly stained (Fig. 1b). A moderately dense AChE-positive innervation was observed in the fibrous capsule. Some of these fine cholinergic fibres entered the zona glomerulosa layer and terminated among the parenchymal cells and/or around the vessels (Fig. 1c). Others penetrated a short distance into the zona fasciculata before turning back into the zona glomerulosa. Occasionally still others traversed the cortex without ramification, and ended in either the medulla or isolated patches of chromaffin cells, which were also strongly stained (Fig. 1d).

Incubations in the presence or absence of the pseudocholinesterase inhibitor, iso-OMPA, resulted in the same staining pattern. Staining was abolished by omission of the endogenous substrate from the incubation medium, or by addition of the cholinesterase inhibitor, physostigmine, to the incubation medium (negative controls; Fig. 1a).

Light- and electron-microscopic immunolabelling for ChAT The very fine cholinergic nerves revealed by AchE cytochemistry in the adrenal gland were not visible as immunolabelled structures by light microscopy, although very prominent immunolabelling for ChAT could be seen in sections from brain medial septum ('positive control', Fig. 2a). However, here the perikarya and the thick dendrites of the cholinergic neurones were strongly labelled, but once again the fine axons were not visible (Fig. 2a).

At the electron microscopic level some immunolabelled cholinergic varicose axon terminals were occasionally seen in the capsule-glomerulosa region of the adrenal (Fig. 2d). These cholinergic varicose axon terminals did not form synaptic contact with zona glomerulosa cells or vascular endothelial or smooth muscle cells, or with other cells of the connective tissue. Mostly these cholinergic varicose axon terminals did not occur singly, but together with other non-cholinergic (unstained) varicose axon terminals (Fig. 2d).

At the electron microscopic level, immunocytochemistry showed cholinergic and non-cholinergic nerve profiles together in the same bundles (Fig. 2b) and cholinergic nerve terminals formed synaptic contact with medullary cells (Fig. 2c). In general, these cholinergic structures were very thin and fine, and less dense than indicated by the histochemical staining for AChE. Control sections, which were not exposed to primary antibody, showed no staining. 

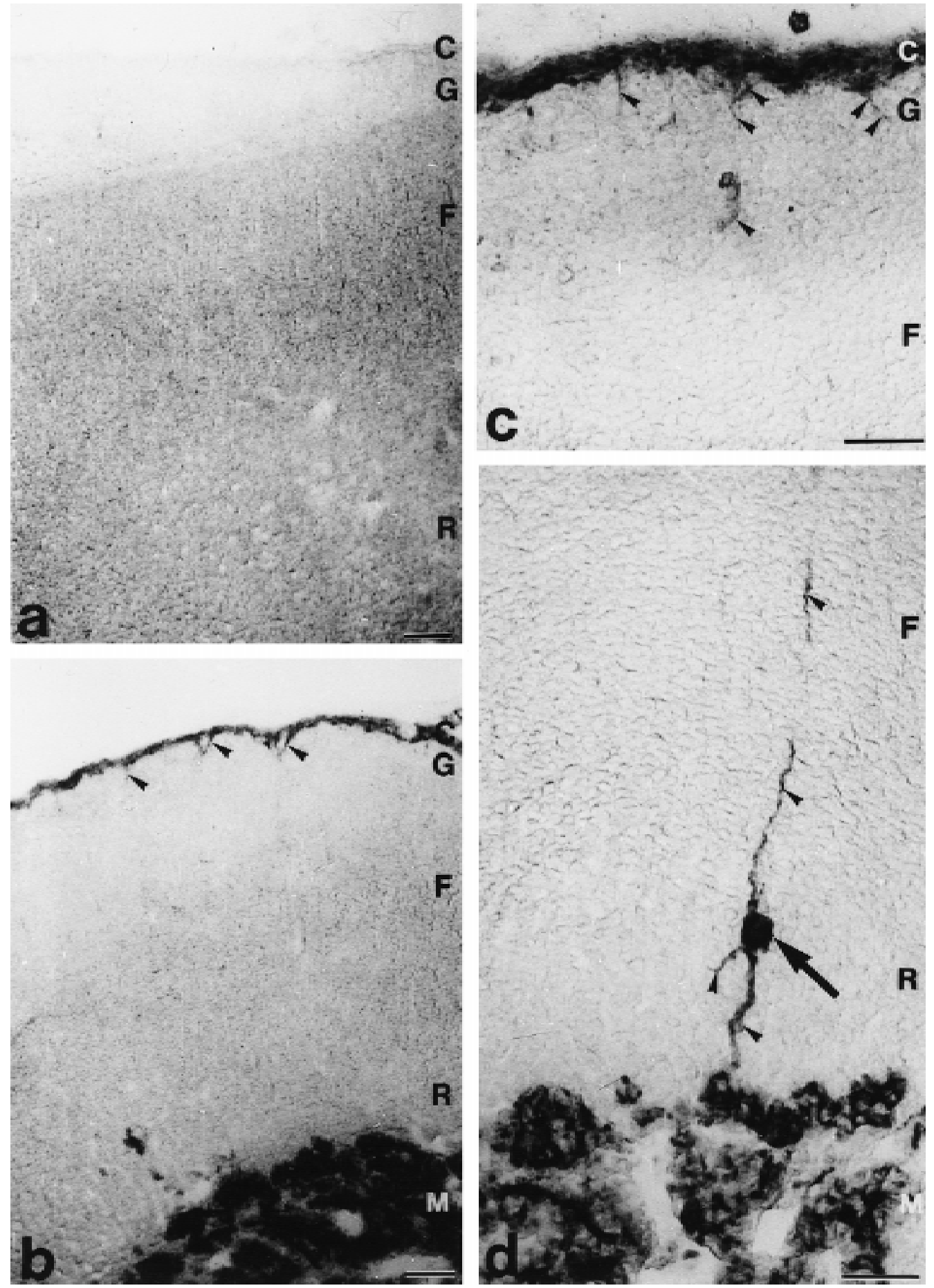

Figure 1 Cholinergic structures in the rat adrenal gland. Enzyme histochemical demonstration of AChE by light microscopy. (a) Negative control: there is no labelling when substrate is omitted. (b) Fine nerve fibres (arrowheads) in the capsule-glomerulosa region and strongly labelled adrenal medulla $(\mathrm{M})$ are visible as cholinergic structures. (c) Fine cholinergic neural arborization (arrowheads) in the capsule-glomerulosa region (in the presence of pseudocholinesterase inhibitor). (d) A cholinergic nerve fibre (arrowheads) traverses radially through the zona fasciculata and reticularis. Both adrenal medulla $(\mathrm{M})$ and a small chromaffin cell islet (arrow) are strongly stained. Scale bars: $100 \mu \mathrm{m}$. Abbreviations: C, capsular connective tissue; G, zona glomerulosa; $F$, zona fasciculata; $R$, zona reticularis; $M$, adrenal medulla. 

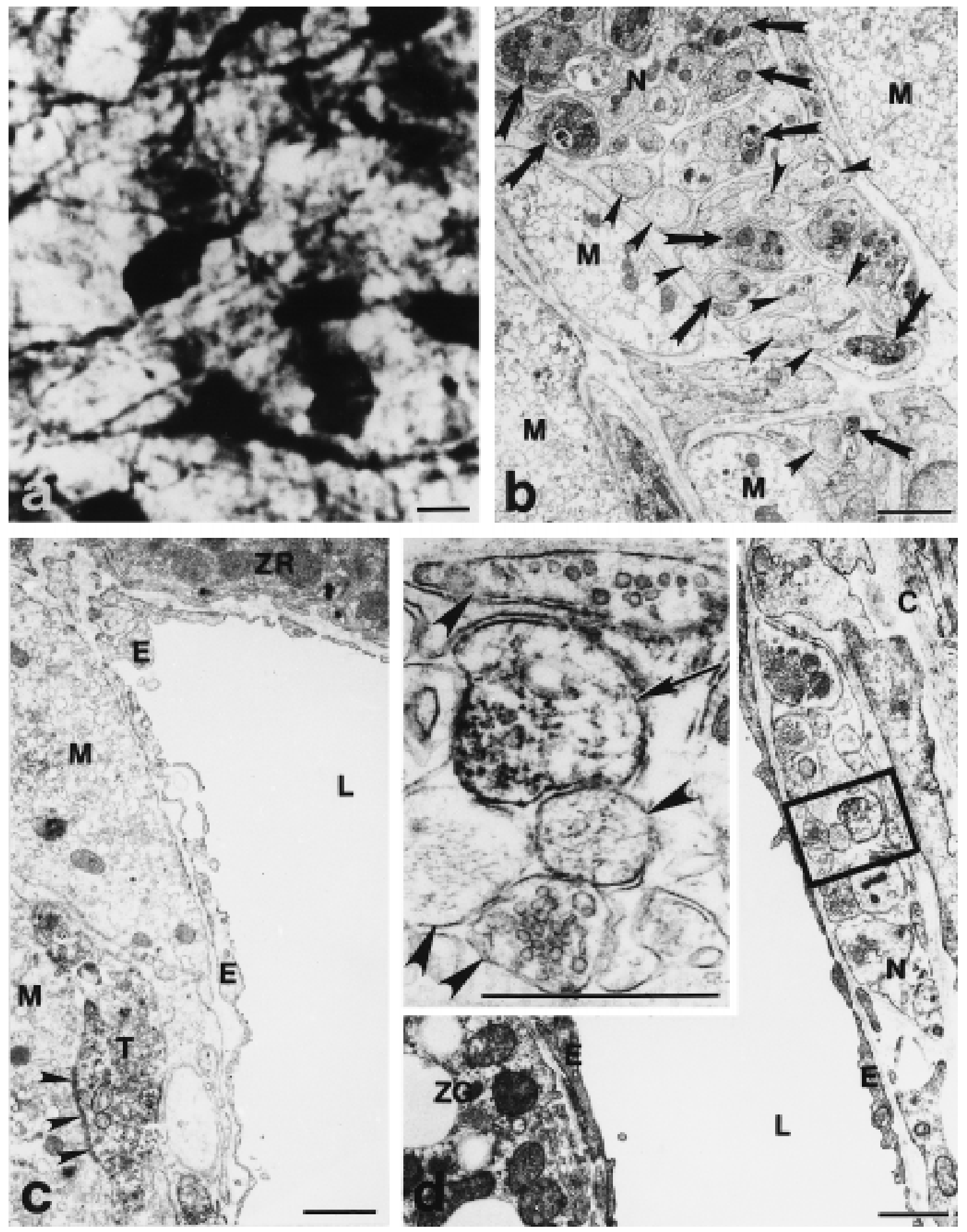

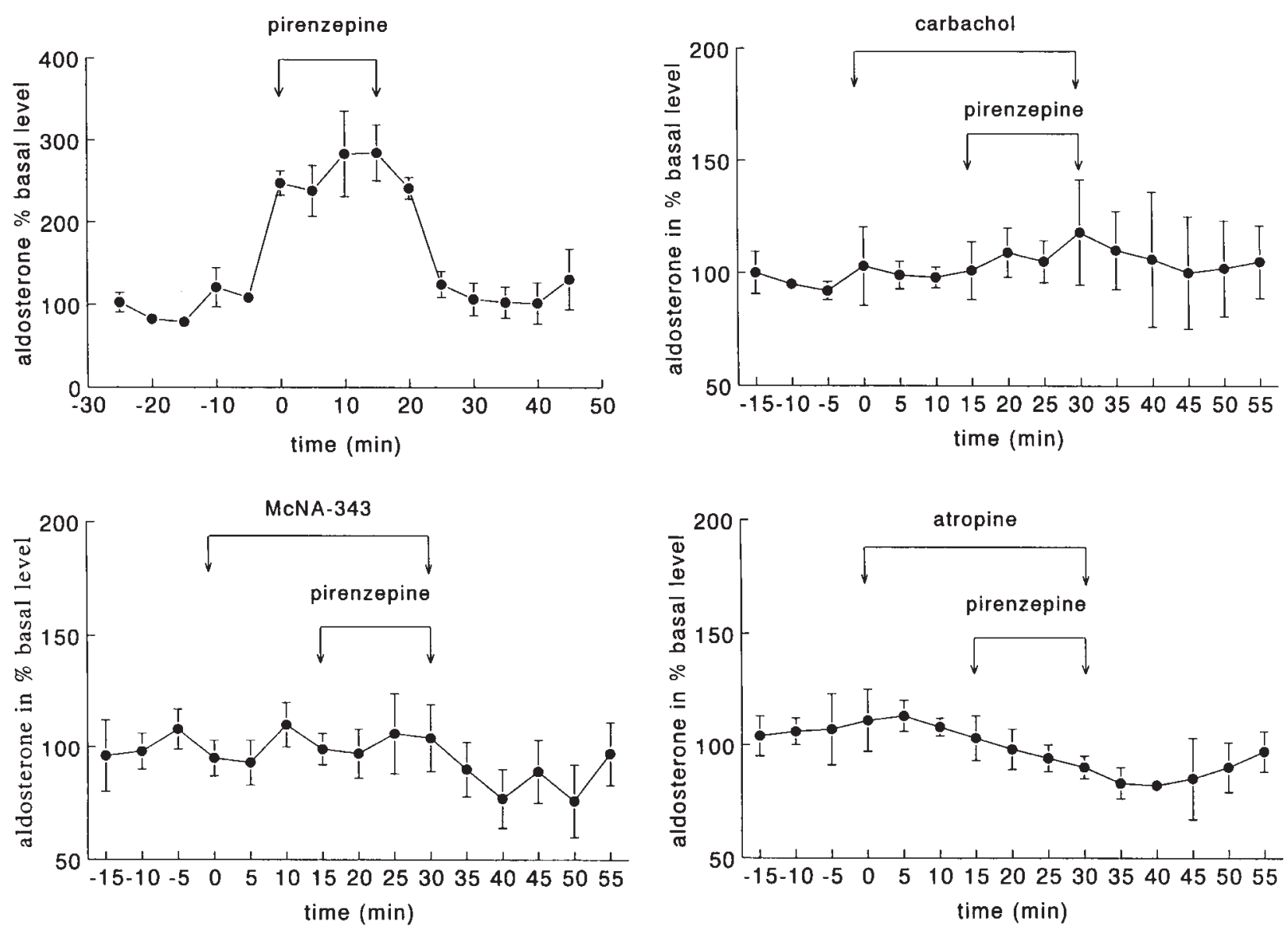

Figure 3 Time course for pirenzepine $(10 \mu \mathrm{M})$-induced aldosterone secretion. Pirenzepine was infused for 20 min. At rest, the aldosterone mean secretion rate was $8 \cdot 5 \pm 2 \cdot 3 \mathrm{pmol} / \mathrm{ml}$ per $5 \mathrm{~min}$. Pirenzepine $(10 \mu \mathrm{M})$-induced aldosterone secretion was abolished by $1 \mathrm{mM}$ carbachol, $500 \mu \mathrm{M}$ McN-A-343 and $10 \mu \mathrm{M}$ atropine. Carbachol, McN-A-343 and atropine were infused 15 min before and during infusion of pirenzepine. Aldosterone mean secretion rates were (basal) $1 \cdot 1 \pm 0 \cdot 3$, and $10 \cdot 5 \pm 3 \cdot 1$ and $5 \cdot 7 \pm 0 \cdot 6 \mathrm{pmol} / \mathrm{ml}$ per $5 \mathrm{~min}$ for McN-A-343 and atropine respectively. Values are means \pm S.E.M. for five, four, four and three experiments for pirenzepine, carbachol, McN-A-343 and atropine respectively.

\section{Cholinergic effects on aldosterone production}

ACh content of capsule-glomerulosa Endogenous ACh content was measured by bioassay in freshly isolated capsule-glomerulosa preparations and found to be $0 \cdot 7 \pm 0 \cdot 2 \mu \mathrm{g} / \mathrm{g}$ wet weight $(n=11)$.
Effect of $\mathrm{ACh}$ and muscarinic antagonists on aldosterone secretion ACh $(1 \mathrm{mM})$ had a varying effect on steroid secretion. In four out of seven experiments a significant $(200-500 \%)$ rise was seen in aldosterone, but no change in the level of steroid production was observed in the other three cases. Carbachol

Figure 2 Cholinergic structures in rat septum and adrenal gland. Immunocytochemical demonstration of ChAT at light and electron microscopic level. (a) Light micrograph from a part of rat brain. Strongly labelled perikarya and thick dendrites are shown, but the very fine axons are not visible. (b) Electron micrograph from the adrenal medulla. Cholinergic (arrows) and non-cholinergic (arrowheads) nerves occur together in the same bundle among medullary cells. (c) Electron micrograph from the border of the adrenal medulla and cortex (zona reticularis). A cholinergic axon terminal (T) forms a synaptic contact on a medullary cell (M) (arrowheads). (d) Electron micrograph from the capsule-glomerulosa region. A perivascular nerve profile $(\mathrm{N})$ containing cholinergic (see inset, arrow) and non-cholinergic (see inset arrowheads) axons are indicated. Scale bars: $\mathrm{a}, 10 \mu \mathrm{m} ; \mathrm{b}-\mathrm{d}$ and inset, $1 \mu \mathrm{m}$. Abbreviations: $\mathrm{M}$, medullary cell; $\mathrm{N}$, nerve profile; E, endothelial cell; L, lumen of vessel; ZR, zona reticularis cell; ZG, zona glomerulosa cell; T, axon terminal; C, adrenal capsule/capsular connective tissue. 
Table 1 Effect of different muscarinic antagonists on aldosterone secretion. Data are means \pm S.E.M. for the number of experiments shown in parentheses

\begin{tabular}{lc} 
& $\begin{array}{c}\text { Aldosterone (\% basal } \\
\text { level of } 20 \text { min infusion) }\end{array}$ \\
\cline { 2 - 2 } Drug & \\
Pirenzepine $1 \mu \mathrm{M}$ & $122 \pm 3(6)$ \\
$10 \mu \mathrm{M}$ & $263 \pm 14(5)^{*}$ \\
$100 \mu \mathrm{M}$ & $240 \pm 4(6)^{*}$ \\
Atropine $10 \mu \mathrm{M}$ & $95 \pm 5(4)$ \\
4-DAMP $10 \mu \mathrm{M}$ & $105 \pm 7(3)$ \\
Methoctramine $10 \mu \mathrm{M}$ & $97 \pm 5(4)$ \\
&
\end{tabular}

All antagonists were infused for $20 \mathrm{~min}$. ${ }^{*} P<0 \cdot 001$ (one-way ANOVA, Scheffé test).

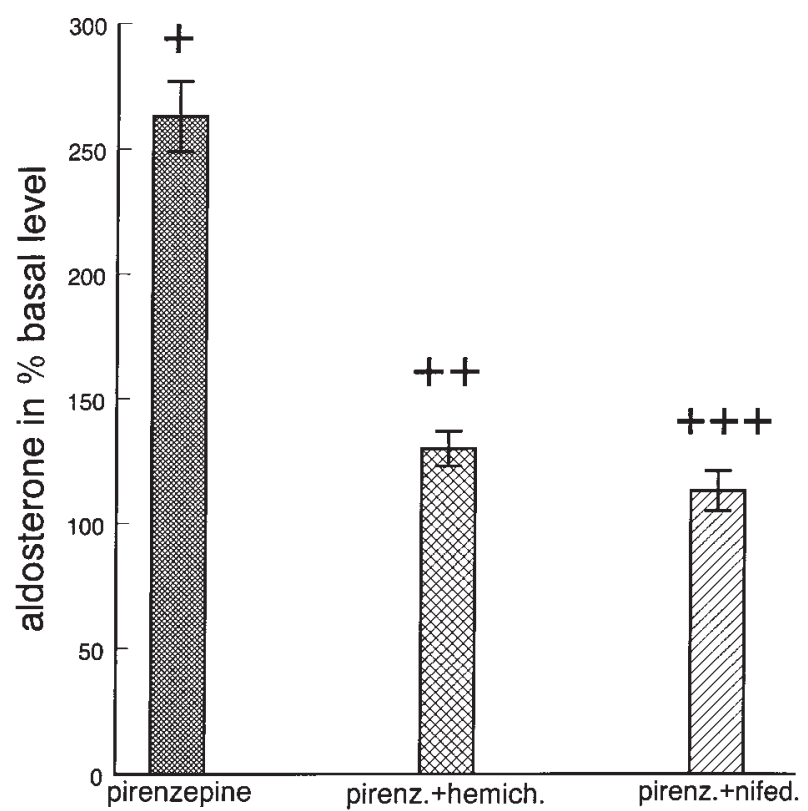

Figure 4 Comparison of the effects of pirenzepine (pirenz.) alone and in combination with hemicholine (hemich.) or nifedipine (nifed.). Pirenzepine was infused for $20 \mathrm{~min}$, hemicholine for $2 \mathrm{~h}$ before and during infusion of pirenzepine, nifedipine for $20 \mathrm{~min}$ before and during infusion of pirenzepine. ${ }^{+} P<0 \cdot 001$ compared with control (one-way ANOVA, Scheffé test), ${ }^{++} P<0 \cdot 01$ compared with control and $P<0.01$ compared with pirenzepine alone (two-way ANOVA, Scheffé test), ${ }^{+++} P>0.5$ compared with control (one-way ANOVA, Scheffé test). Values are the mean \pm S.E.M. of 20 min collection time for five, five and four experiments respectively. At rest the mean rates of aldosterone secretion were $3.4 \pm 1 \cdot 6,1 \cdot 1 \pm 0.3$ and $10.5 \pm 3 \cdot 1 \mathrm{pmol} / \mathrm{ml}$ per $5 \mathrm{~min}$ for pirenzepine, pirenz.+hemich. and pirenz.+nifed. respectively.

affected aldosterone secretion similarly to ACh (data not shown).

Since endogenous ACh was present in the tissues, we performed a set of experiments to study whether antagonists alone could affect steroid secretion. Pirenzepine (10 and $100 \mu \mathrm{M}$ ) (selective $\mathrm{M}_{1}$ antagonist at low concentrations, $\mathrm{M}_{1}$ and $\mathrm{M}_{2}$ antagonist at higher concentrations) stimulated aldosterone secretion (Fig. 3, Table 1). This stimulation was abolished by co-incubation with carbachol $(1 \mathrm{mM})$, the $\mathrm{M}_{1}$ agonist $\mathrm{McN}-\mathrm{A}-343(500 \mu \mathrm{M})$ and the muscarinic antagonist atropine $(10 \mu \mathrm{M})$ (Fig. 3). On the other hand, atropine (non-selective muscarinic antagonist), 4-DAMP (selective $\mathrm{M}_{1}-\mathrm{M}_{3}$ antagonist) and methoctramine (selective $\mathrm{M}_{2}$ antagonist) had no effect on steroid output (Table 1). To prove further that endogenous ACh mediated the effect of pirenzepine, the capsule-glomerulosa preparation was perifused with hemicholine (choline uptake blocker) for $2 \mathrm{~h}$ before the addition of pirenzepine. Hemicholine significantly reduced, although did not completely abolish, the effect of pirenzepine (Fig. 4). Hemicholine alone had no effect on aldosterone secretion (data not shown).

The finding that pirenzepine acutely enhanced aldosterone secretion suggests that pirenzepine may act directly, by opening ion channels. To test this hypothesis, the $\mathrm{Ca}^{2+}$ channel blocker nifedipine was infused concomitantly with pirenzepine. The results show that nifedipine abolished the effect of pirenzepine (Fig. 4). Nifedipine alone had no effect on aldosterone secretion (data not shown).

Identification of muscarinic receptor subtypes Nonsubtype-specific radioligand QNB bound to muscarinic receptors with high affinity $\left(K_{\mathrm{d}} 0.08 \mathrm{nM}\right)$ and revealed a total receptor number of $7 \cdot 3 \mathrm{fmol} / \mathrm{mg}$ protein. Specific binding was saturable, and non-specific binding was less than $10 \%$ of total binding (Fig. 5). In competition studies, subtype specificity was investigated against $\left[{ }^{3} \mathrm{H}\right] \mathrm{QNB}$ by use of the non-selective antagonist atropine and the $\mathrm{M}_{1^{-}}$, $\mathrm{M}_{2^{-}}$and $\mathrm{M}_{3}$-selective antagonists pirenzepine, methoctramine and 4-DAMP respectively. The following rank order of potency of binding was revealed: atropine $\geq 4$ DAMP $>>$ methoctramine $>$ pirenzepine (Table 2).

\section{Discussion}

Presence of cholinergic nerves in the capsule-glomerulosa region

The presence of cholinergic neuronal elements in the rat adrenal gland was demonstrated by histochemistry for AChE and immunocytochemistry for ChAT. Most cholinergic fibres terminated on chromaffin cells in the medulla or in islets within the cortex, and formed synaptic contacts with them. In agreement with other authors, we decided that the majority of these cholinergic fibres may represent the preganglionic innervation of medullary cells (for reviews see Kesse et al. 1988, Tomlinson \& Coupland 1990, Parker et al. 1994). In addition to preganglionic adrenal innervation, a thin cholinergic neural network was also demonstrated in the capsule-glomerulosa region. Such fine cholinergic fibres may participate in the formation of the subcapsular plexus. Some of these cholinergic 


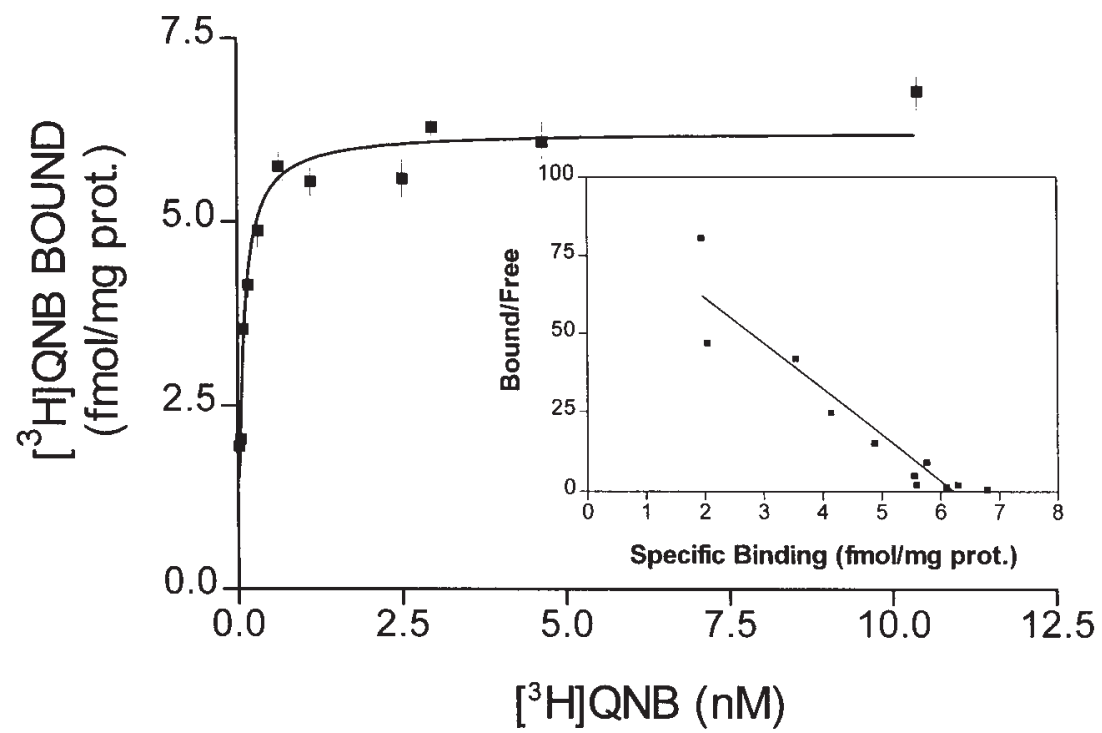

Figure 5 Saturation curve of specific binding of $\left[{ }^{3} \mathrm{H}\right] \mathrm{QNB}$ to membranes from the capsule-glomerulosa. Each point is defined as total binding, determined in triplicate, minus non-specific binding, determined in duplicate. Non-specific binding was $<10 \%$ of total binding. In the experiment shown $K_{\mathrm{d}}=0.074 \mathrm{nM}$ and $\mathrm{B}_{\max }=6.6 \mathrm{fmol} / \mathrm{mg}$ protein. Inset: Scatchard transformation of the specific binding data.

nerves in the subcapsular plexus gave branches to the zona glomerulosa cells or to local blood vessels, and terminated in the capsule-glomerulosa region. These cholinergic fibres may represent the postganglionic parasympathetic innervation of the capsule-glomerulosa region (see Kesse et al. 1988, Tomlinson \& Coupland 1990, Parker et al. 1993, 1994). It is probable that only these postganglionic cholinergic varicose axon terminals (and not the preganglionic fibres, which are in the medulla) take part in the local direct neural modulation of zona glomerulosa function.

Stereological analysis of the innervation of the rat adrenal capsule-glomerulosa region (Vizi et al. 1992, Orsó et al. 1992) revealed that about $50 \%$ of the local innervation is catecholaminergic, with cholinergic nerves among the remainder. Accordingly it might perhaps have been expected that the cholinergic innervation would be more dense than the present results show.

Table 2 Affinities of muscarinic receptor antagonists in competing for specific $\left[{ }^{3} \mathrm{H}\right] \mathrm{QNB}(0 \cdot 1 \mathrm{nM})$ binding in capsule-glomerulosa homogenates. Data are means \pm S.E.M.. for the number of experiments shown in parentheses

\begin{tabular}{|c|c|c|}
\hline & $\begin{array}{l}\text { Receptor } \\
\text { selectivity }\end{array}$ & $\boldsymbol{K}_{\mathbf{i}}(\mathrm{nM})$ \\
\hline \multicolumn{3}{|l|}{ Drug } \\
\hline Atropine & Non-subtype & $1 \cdot 3 \pm 0 \cdot 2$ \\
\hline 4-DAMP & $\mathrm{M} 1 / \mathrm{M} 3$ & $3 \cdot 1 \pm 1 \cdot 2$ \\
\hline Methoctramine & M2 & $99 \cdot 2 \pm 3 \cdot 8$ \\
\hline Pirenzepine & M1 & $408 \cdot 3 \pm 81 \cdot 6(3)$ \\
\hline
\end{tabular}

The histochemical method used for AChE is a very sensitive but less specific technique than immunolabelling for ChAT, or for other markers of cholinergic structures. With the application of the specific pseudocholinesterase inhibitor iso-OMPA, the specificity of AchE histochemistry can be improved so that it becomes an acceptable marker for cholinergic structures. However, it has been shown that the presence of AChE is not an obligatory criterion of cholinergic structures (Kasa 1986). It is preferable for this reason to combine AchE histochemistry with immunocytochemical technique(s).

Using light microscopy, although cholinergic perikarya and thick dendrites could clearly be demonstrated by ChAT immunostaining in the medial septum of the brain, the technical limitations of the light microscopic method (cf. Tago et al. 1987) precluded observation of these very thin cholinergic axons in the adrenal, and indeed in medial septal sections. Cholinergic nerves and cholinergic varicose axon terminals were, however, demonstrated in the capsule-glomerulosa region by AchE histochemistry and immunocytochemistry for ChAT at the electron microscopic level.

\section{Increased secretion of aldosterone on stimulation by ACh in rat} capsule-glomerulosa

Using an isolated capsule-glomerulosa preparation in the microvolume superfusion system, functional evidence was obtained that $\mathrm{ACh}$ affects aldosterone production in the zona glomerulosa. In contrast with Kojima et al. (1986) and 


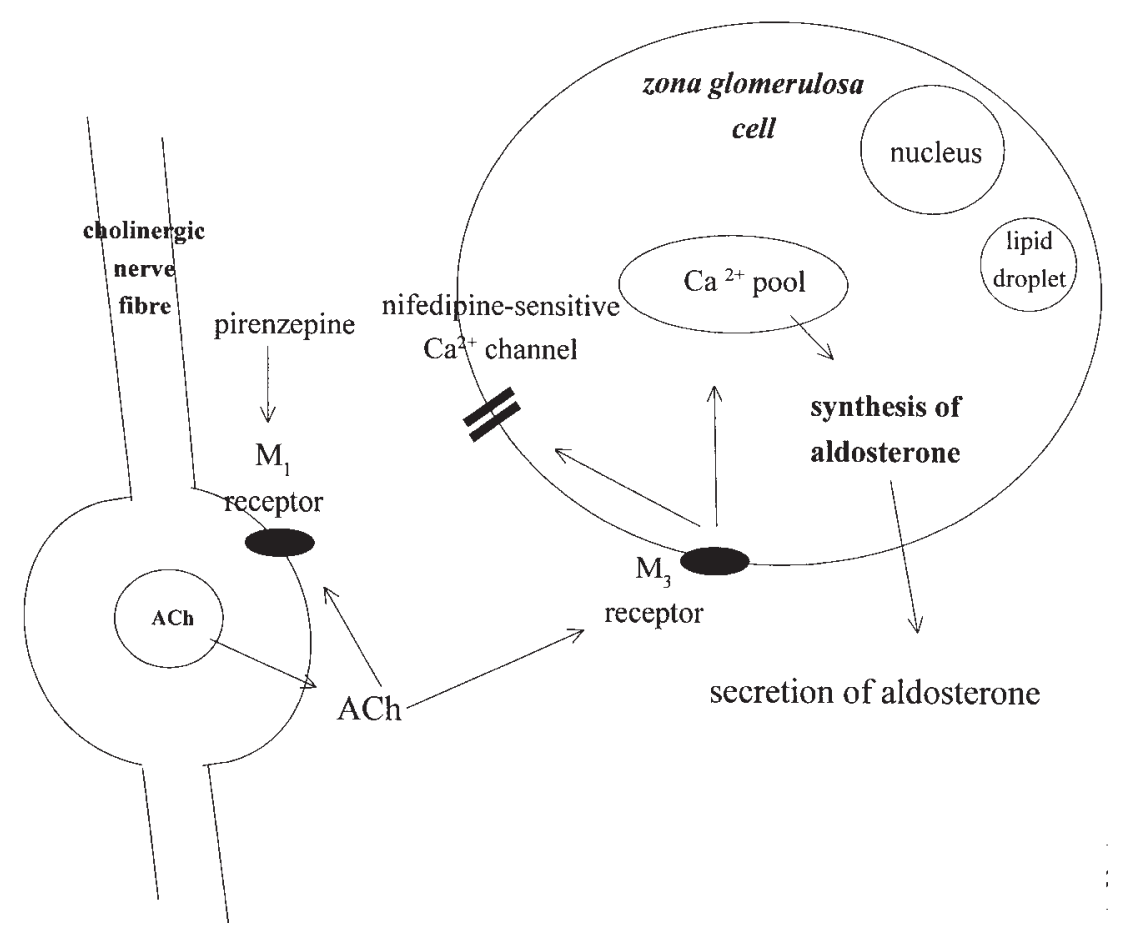

Figure 6 Cholinergic actions on the zona glomerulosa cell. ACh is released in close proximity to the zona glomerulosa cell and induces both $\mathrm{Ca}^{2+}$ channel opening and $\mathrm{Ca}^{2+}$ release from intracellular pools, eventually leading to synthesis and secretion of aldosterone. It is suggested that pirenzepine acts on presynaptic $M_{1}$ autoreceptors to increase spontaneous $A C h$ release which, in turn, through $M_{3}$ receptors on the postsynaptic side, increase aldosterone synthesis.

Porter et al. (1988), who observed a systematic increase in steroid output after ACh administration in dispersed bovine adrenocortical cell and rat perfused gland preparations respectively, the actions of $\mathrm{ACh}$ on aldosterone secretion in the present experiments were variable. This may be due to differences in the systems used. Several studies have pointed out that freshly isolated tissue or dispersed cells may respond poorly to some stimulants compared with in vivo or in vitro tissue culture preparations (DeLean et al. 1984, Kawamura et al. 1985, Pratt et al. 1985). In one study (Gallo-Payet et al. 1993), the relative unresponsiveness of freshly isolated tissue was attributed to the high level of basal inositol phosphate production and steroid secretion. According to these authors, freshly isolated tissues exhibit very high basal intracellular free $\mathrm{Ca}^{2+}$ concentrations which inhibit further stimulation of corticosteroid secretion. This could explain the unresponsiveness of the tissue in our experiments except on some occasions when agonists were used in high concentrations.

In contrast with the relatively weak effect of agonist stimulation, a functional role for cholinergic innervation of the adrenal cortex was fully supported by the increase in aldosterone secretion induced by pirenzepine. This effect was mediated by muscarinic receptors since it was abol- ished by carbachol, McNA-343 and atropine. Our data showing that the action of pirenzepine was blocked by nifedipine (calcium channel blocker) suggest that pirenzepine provides an acute stimulus by enhancing $\mathrm{Ca}^{2+}$ inflow. The findings that pretreatment of the tissue with hemicholine reduced the effect of pirenzepine suggests that endogenous $\mathrm{ACh}$ is responsible for stimulating aldosterone secretion. Although in the first place this result may reflect tonic inhibition of steroid synthesis by endogenous $\mathrm{ACh}$, it seems unlikely, since high concentrations of ACh should have overcome the inhibitory effect of endogenous $\mathrm{ACh}$ and resulted in a systematic increase in steroid output. Our observation that infusion of hemicholine, a choline uptake blocker, did not increase basal aldosterone production is also in contrast with this assumption. For these reasons it is hypothesized that pirenzepine acts on presynaptic autoreceptors responsible for the negative feedback modulation of ACh release, and thus increases spontaneous $\mathrm{ACh}$ release from varicose axon terminals. According to this model, ACh would be released in close proximity to the glomerulosa cells and acutely stimulate steroidogenesis through postsynaptic receptors. Such presynaptic inhibition of muscarinic autoreceptors has been demonstrated by many authors (for a review see Vizi 1984). Several authors showed that 
neurotransmitter release can be modulated through presynaptic inhibitory $M_{1}$ receptors (Eltze 1988, Brehm et al. 1992, Shannon et al. 1993). For example, Kawashima et al. (1988) found that by abolishing inhibition of presynaptic $M_{1}$ receptors, pirenzepine enhanced $A C h$ release and caused contraction in longitudinal muscle strips of guinea pig ileum. The cholinergic effect presumably acts through the $\mathrm{M}_{1}$ receptor, since $\mathrm{McN}-\mathrm{A}-343$ ( $\mathrm{M}_{1}$ agonist) prevented the response of aldosterone to pirenzepine action (which is usually an $M_{1}$ antagonist). Drug selectivity was important in eliciting an effect, since other antagonists, including the non-selective antagonist atropine, did not influence steroid production. Since atropine abolished the effect of pirenzepine, these data suggest that at least two muscarinic receptor subtypes may exist in the capsule-glomerulosa. It seems likely that the increase in aldosterone secretion in response to endogenous $\mathrm{ACh}$ is mediated through the $\mathrm{M}_{3}$ receptor. Receptor-binding assays of $\left[{ }^{3} \mathrm{H}\right] \mathrm{QNB}$ indicated that glomerulosa cells are equipped with specific homogeneous muscarinic receptorbinding sites. Results of competition studies showed that muscarinic receptors have high affinity for atropine and 4-DAMP and low affinity for methoctramine and pirenzepine, which suggests that the muscarinic receptor is the $\mathrm{M}_{3}$ subtype. An overview of the suggested mechanism of cholinergic action on zona glomerulosa cells is shown in Fig. 6.

In conclusion, these results demonstrate that cholinergic nerve fibres are present in the zona glomerulosa of the rat adrenal and can influence steroidogenesis. The findings are consistent with the general thesis that we have advanced in recent years, that, in addition to the well-established role of systemic hormones in the control of steroid hormone secretion by the adrenal cortex, there is ample evidence that rapid and sensitive neural mechanisms are also involved (Tóth et al. 1997). The gland is clearly capable of responding to physiological demand with great flexibility, in a manner that depends at least in part on the paracrine interactions of different cell types.

\section{Acknowledgements}

This study was supported by the Hungarian Research Fund (T-6146 and F 016332) and the Wellcome Trust. The authors are grateful to Dr Louis B Hersh (University of Kentucky, Lexington, KY, USA) for the generous gift of the antiserum against ChAT. The expert technical assistance of Ms Anna Freytag, Ms Erzsébet Römmer and Mr Gábor Terstyánszky is appreciated.

\section{References}

Amstrong DM, Bruce G, Hersh LB \& Gage FH 1987 Development of cholinergic neurons in the septal/diagonal band complex of the rat. Brain Research 433 249-256.
Benyamina M, Leboulenger F, Lirhmann I, Delarue C, Feuilloley M \& Vaudry H 1987 Acetylcholine stimulates steroidogenesis in isolated frog adrenal gland through muscarinic receptors: evidence for a desensitization mechanism. Journal of Endocrinology 113 339-348.

Brehm G, Lindmar R \& Löffelholz 1992 Inhibitory and excitatory muscarinic receptors modulating the release of acetylcholine from the postganglionic parasympathetic neuron of the chicken heart. Naunyn-Schmiedeberg's Archives of Pharmacology 346 375-382.

Charlton BG, Nkomazana OF, McGadey J \& Neal DE 1991 A preliminary study of acetylcholinesterase-positive innervation in the human adrenal cortex. Journal of Anatomy 176 99-104.

DeLean A, Raca K, McNicoll N \& Desrosiers ML 1984 Direct $\beta$-adrenergic stimulation of aldosterone secretion in cultured bovine adrenal subcapsular cells. Endocrinology 115 485-492.

Eltze M 1988 Muscarinic $M_{1}$ and $M_{2}$ receptors mediating opposite effects on neuromuscular transmission in rabbit vas deferens. European Journal of Pharmacology 151 205-221.

Gallot-Payet N, Payet MD, Chouinard L, Balestre MN \& Guillon G 1993 A model for studying regulation of aldosterone secretion: freshly isolated cells or cultured cells? Cellular Signalling 5 651-666.

German DC, Bruce G \& Hersh LB 1985 Immunohistochemical staining of cholinergic neurons in the human brain using a polyclonal antibody to human choline acetyltransferase. Neuroscience Letters 61 1-5.

Hadjian AJ, Guidicelli C \& Chambaz EM 1982 Cholinergic muscarinic stimulation of steroidogenesis in bovine adrenal cortex fasciculata cell suspensions. Biochimica et Biophysica Acta $\mathbf{7 1 4}$ 157-163.

Holzwarth MA, Cunningham LA \& Kleitman N 1987. The role of adrenal nerves in the regulation of adrenocortical functions. Annals of the New York Academy of Sciences 512 449-464.

Jones CT, Edwards AV \& Bloom SR 1991 Endocrine responses to intra-aortic infusions of acetylcholine in conscious calves. Journal of Physiology 439 481-499.

Karnovsky MJ \& Roots L 1964 A 'direct coloring' thiocholine method for cholinesterases. Journal of Histochemistry 12 219-221.

Kasa P 1986 The cholinergic systems in brain and spinal cord. Progress in Neurobiology 26 211-272.

Kawamura M, Yonezawa Y, Tanaka Y, Imagawa N, Tomita C \& Matsuba M 1985 Corticoidogenic effect of acetylcholine in bovine adrenocortical cells. Endocrinologia Japonica 32 17-19.

Kawashima K, Fujimoto K, Suzuki T \& Oohata H 1988 Direct determination of acetylcholine release by radioimmunoassay and presence of presynaptic M1 muscarinic receptors in guinea pig ileum. Journal of Pharmacology and Experimental Therapeutics 244 1036-1039.

Kesse WK, Parker TL \& Coupland RE 1988 The innervation of the adrenal gland. I. The source of pre- and postganglionic nerve fibres to the rat adrenal gland. Journal of Anatomy 157 33-41.

Kojima I, Kojima K, Shibata H \& Ogata E 1986 Mechanism of cholinergic stimulation of aldosterone secretion in bovine adrenal glomerulosa cells. Endocrinology 119 284-291.

Kovács K \& Horváth E 1973 Corticomedullary cells in a human adrenal cortical adenoma and in rat adrenal cortex. Anatomischer Anzeiger 134 387-389.

Orsó E, Tóth IE, Szalay KSz, Szabó D, Vinson GP \& Vizi ES 1992 Catecholaminergic nerve endings in capsule-glomerulosa preparation: distribution and a possible role. In Electron Microscopy 92, vol III (Proceedings of the 10th EUREM), pp 863-864. Eds L Megías-Megías MI Rodríguez-García, A Ríos \& JM Arias. Granada: Secretariado de Publicationes de la Universidad de Granada.

Palacios G \& Lafarga M 1975 Chromaffin cells in the glomerular zone of adult rat adrenal cortex. Cell and Tissue Research 164 275-278.

Parker TL, Kesse WK, Mohamed AA \& Afework M 1993 The innervation of the mammalian adrenal gland. Journal of Anatomy 183 265-276. 
Parker TL, Mohamed AA \& Coupland RE 1994 The innervation of the adrenal gland. IV. The source of pre- and postganglionic nerve fibres to the guinea-pig adrenal gland. Cell and Tissue Research 275 201-213.

Porter ID, Whitehouse BJ, Taylor AH \& Nussey SS 1988 Effect of arginine vasopressin and oxytocin on acetylcholine-stimulation of corticosteroid and catecholamine secretion from the rat adrenal gland perfused in situ. Neuropeptides 12 265-271.

Pratt HJ, Turner AD, McAteer AJ \& Henry PD $1985 \beta$-Adrenergic stimulation of aldosterone production by rat adrenal capsular explants. Endocrinology 117 1189-1194.

Purwar RS 1978 Neuro-histochemical study of the adrenal gland of Rattus rattus rufescens (Indian black rat) as revealed by cholinesterase technique. Acta Anatomica 102 29-32.

Shannon E H, Sawyer D B, Bemis G K, Bymaster P F, Heath I, Mitch H C \& Ward S J 1993 Muscarinic M 1 receptor agonist actions of muscarinic receptor agonists in rabbit vas deferens. European Journal of Pharmacology 232 47-57.

Stern N, Pullen W, Plasko R, Eggena P \& Tuck ML 1989 Evidence for cholinergic modulation of aldosterone secretion in man. Journal of Clinical Endocrinology and Metabolism 69 294-298.

Szalay KSz 1981 Effect of pituitary intermediate lobe extract on steroid production by the isolated zona glomerulosa and zona fasciculata cells. Acta Physiologica Academiae Scientiarum Hungaricae 57 225-231.

Tago H, McGeer PL, Bruce G \& Hersh LB 1987 Distribution of choline acetyltransferase-containing neurons of the hypothalamus. Brain Research 415 49-62.

Tomlinson A \& Coupland RE 1990 The innervation of the adrenal gland. IV. Innervation of the rat adrenal medulla from birth to old age. A descriptive and quantitative morphometric and biochemical study of the innervation of chromaffin cells and adrenal medullary neurones in Wistar rats. Journal of Anatomy 169 209-236.

Tóth IE, Vizi ES, Hinson JP \& Vinson GP 1997 Innervation of the adrenal cortex, its physiological relevance, with primary focus on the noradrenergic transmission. Histology of the Mammalian Adrenal Cortex: Special Issue of Microscopy Research and Technique, vol 36, pp 534-545. Ed. GG Nussdorfer. New York: Wiley-Liss.
Vinson GP, Hinson JP \& Tóth IE 1994 The neuroendocrinology of the adrenal cortex. Journal of Neuroendocrinology 6 235-246.

Vizi ES 1984 Auto-modulation of transmitter/modulator release (negative and positive feedback modulation). In Non-synaptic Interactions Between Neurons: Modulation of Neurochemical Transmission, pp 112-134. New York: Wiley-Interscience.

Vizi ES, Hársing LG Jr, Duncalf D, Nagashima H, Potter P \& Földes F 1985 A simple and sensitive method of acetylcholine identification and assay. Bioassay combined with minicolumn gel filtration or high-performance liquid chromatography. Journal of Pharmacological Methods 13 201-211.

Vizi ES, Tóth IE, Szalay KSz, Windisch K, Orsó E, Szabó D \& Vinson GP 1992 Catecholamines released from local adrenergic axon terminals are possibly involved in fine tuning of steroid secretion from zona glomerulosa cells: functional and morphological evidence. Journal of Endocrinology 135 551-561.

Vizi ES, Tóth IE, Orsó E, Szalay KSz, Szabó D, Baranyi M \& Vinson GP 1993 Dopamine is taken up from the circulation by, and released from local adrenergic varicose axon terminals in zona glomerulosa of the rat: a neurochemical and immunocytochemical study. Journal of Endocrinology 139 213-226.

Walker SW, Strachan MW, Lightly ER, Williams BC \& Bird IM 1990 Acetylcholine stimulates cortisol secretion through the M3 muscarinic receptor linked to a-phosphoinositide-specific phospholipase $\mathrm{C}$ in bovine adrenal fasciculata/reticularis cells. Molecular and Cellular Endocrinology 72 227-238.

Walker SW, Lightly ER, Clyne C, Williams BC \& Bird IM 1991 Adrenergic and cholinergic regulation of cortisol secretion from the zona fasciculata/reticularis of bovine adrenal cortex. Endocrine Research 17 237-265.

Received 21 February 1997

Final version received 17 November 1997 Accepted 22 December 1997 